\title{
WHAT IS INDEPENDENCE AND HOW TO USE IT?
}

\author{
Prof. h. c. mult. Doctor h. c. mult. Fil. Dr. Jan-Urban Sandal
}

Executive Director and Owner of Fil. Dr. Jan-U. Sandal Institute

Excellence in Science and Education

Professor Chair Chernivtsi Schumpeter Centre for Economic Research, Yuriy Fedkovych Chernivtsi National

University, Chernivtsi, Ukraine

Patron of Harvard University Archives, USA

Honorary Professor Chernihiv Polytechnic National University, Chernihiv, Ukraine

Honorary Senior Fellow Science Technology and Training OMEGA Institute, Hanoi, Vietnam

Doctor Honoris Causa Alytaus Kolegija University of Applied Sciences, Alytus, Lithuania

e-mail: jan-u.sandal@janusandal.no

Received: 13 September 2021; $\quad$ Accepted: 13 September 2021; $\quad$ Published: 21 September 2021

JEL classification: A12, H11, O31

Citation: Sandal, Jan-U. (2021). What is independence and how to use it?. Access to science, business, innovation in digital economy, ACCESS Press, 2(3): 309-310. https://doi.org/10.46656/access.2021.2.3(8)

\section{Speech}

September 10, 2021

09.30 - 12.00 PLENNARY SESSION

Taras Shevchenko National University of Kyiv, Kyiv, Ukraine

International Scientific and Practical Conference

\section{"30 YEARS OF INDEPENDENCE OF UKRAINE: ACHIEVEMENTS, CHALLENGES AND PROSPECTS"}

Acting Director of the Educational and Scientific Institute of Public Administration and Civil Service of

Taras Shevchenko National University of Kyiv, Ms. Larysa Komakha has the honor to invite

Professor, Doctor of Philosophy Jan-Urban Sandal to speak at the Plenary Session of the Conference

Dear

Volodymyr Bugrov, Rector of Taras Shevchenko National University of Kyiv, Candidate of Philosophy, Professor, recipient of award for excellence in education of Ukraine, Honored Worker of Education of Ukraine, Larysa Komakha, Acting Director of the Educational and Scientific Institute of Public Administration and Civil Service of Taras Shevchenko National University of Kyiv, Doctor of Philosophy, Professor, 
Members of the main table,

Representatives of the Parliament, Verkhovna Rada of Ukraine,

Distinguished Guests,

Ladies and Gentlemen,

Today we gather in the name of science to celebrate 30 years of independence for Ukraine. Our task is to understand, on a deeper level, three decades of independence in Ukraine, the development of national parliamentarism and the challenges the nation will inevitably face on the way forward.

What is independence and how to use it is my question. The relevance and significance of the question has the quality of capturing the attention of everyone these days. Does independence mean that the president and the parliament are independent of the people? Alternatively, is it the other way around that the people now and in the future can live a good life based on democratic values and independently? Institutional arrangements that are intended to govern based on the will of the people to achieve the common good, do not necessarily or automatically reflect democratic values and way of living or individual conduct of life. Inclusive rule that constitute collecting wealth from the many to gain the few is only one of the dangers of electoral democratic superstructures as a basic and central political belief. Too often people`s trust and hope for a better world and a better life have been stopped and crushed because of political propaganda, the rule based on horrifying ideologies and religious lies. In every democracy, the dignity of the political actors depends on the acceptance of the common person. This fact contrasts with the situation regarding the entrepreneur, the creator of civilization throughout history dating back to the Neolithic Revolution as well as International Independent Science, which is the locomotive for democracy building around the world today. One should not forget that parliamentarism and political independence are the fruits of economic growth, a process that began almost three centuries ago. So how can we use independence? The method is obvious to everyone: Lay down your weapons; take up the sword, the word is the sword, but only when it represents the truth, International Independent Science is the truth, free from political propaganda, corruption and fraud, terrible ideologies and religious lies, and promotes a better life for all and peace on earth.

Rector, Acting Director, Members of the main table, Representatives of the Parliament Verkhovna Rada of Ukraine, Distinguished Guests, Ladies and Gentlemen:

Thank you very much for the attention.

Prof. h. c. mult. Doctor h. c. mult. Fil. Dr. Jan-Urban Sandal

Executive Director and Owner of Fil. Dr. Jan-U. Sandal Institute

ORCID ID 0000-0001-8072-0822 